\title{
ADVANTAGES AND DISADVANTAGES OF ARABIC DICTIONARY APPLYING MORPHOLOGICAL SYSTEM FOR LEARNING ARABIC IN INDONESIA
}

\section{R. Taufiqurrochman}

\author{
taufiq@uin-malang.ac.id \\ Universitas Islam Negeri Maulana Malik Ibrahim \\ Malang, Indonesia
}

\begin{abstract}
The growth of the Arabic dictionary in Indonesia begins with the emergence of an Arabic dictionary applying morphological systems (nizam sharfi). However, it is problematic in Arabic learning, especially at the beginner level. This article presents the advantages, disadvantages, and implications of the dictionary, applying a morphological system for Arabic learning in Indonesia. Lexicological and lexicographical analysis of the Arabic dictionary in Indonesia and a survey on dictionary users are applied. The study found that the dictionary with a morphological system has complete entries and subentries contents, helpful for reading Arabic traditional text (Kitab Kuning). The weakness of the dictionary, especially for students at the primary level, is that the dictionary is challenging to use because it requires the basics of Sharaf knowledge (morphology), besides its unhandy size, high price, and the incorrect translation. Indeed, the dictionary helps santri to read Arabic traditional text in Islamic boarding schools because a morphological system is considered being compatible with the method of reading and translation style of Pesantren Salaf (traditional Islamic boarding schools). However, it is only suitable for students at intermediate and advanced levels, not for students at the beginner level who have not yet learned the basics of morphology.
\end{abstract}

Keywords: Dictionary, Morphological System, Arabic Learning

\section{INTRODUCTION}

The history of Arabic development and its learning in Indonesia cannot be separated from the existence of the Arabic dictionary. Since Indonesia was in the colonial period, the Arabic-Malay dictionary had existed in Nusantara (the Indonesian Archipelago) before the emergence of the Arabic-Indonesian dictionary. (Abdul Wahab, 2017) For example, Kamus Arab-Melayu al-Inarah al-Tahdzibiyah by Moehammad Fadloellah and B.Th. Brondgeest (1925), kamus Arab-Melayu alMarbawi by Muhammad Idris al-Marbawi (1927), and kamus Arab-Melayu al-Dzahabi by Mahmud Yunus (1930) (Rizani, 2014). After the Indonesia independence day in 1945, the translations from Arabic to Indonesian just emerged, such as the Kamus Arab-Indonesia by Mahmud Yunus (1972), the Kamus ArabIndonesia al-Kautsar by Husen al-Habsyi
(1977), Kamus Arab-Indonesia by Ahmad Warson Munawwir (1984), Kamus Kontemporer al-Ashri Arab-Indonesia by Atabik Ali and Ahmad Zuhdi Muhdlor (1996), Kamus al-Bisri Indonesian-Arab Arab-Indonesian by Adib Bisri and Munawwir (1999), and so forth.(Busro, 2016) Until now, Arabic dictionaries continue to emerge with a variety of types, systematic, size, and different characters.

This phenomenon shows the urgency of Arabic dictionaries for Indonesian society who are not native speakers of Arabic. Therefore, in Arabic learning, the dictionary is a means of translating and a medium for understanding the meaning of words (Wahida, 2017). By using a dictionary, students can find out the origin of words, essential and derivatives words, differences in meaning, synonyms and antonyms, and singular and plural forms. That 
means the dictionary plays a significant role in developing Arabic in Indonesia.

In general, the Arabic dictionaries that were published before and after the Indonesian independence era were a pronunciation dictionary ( $m u^{\prime} j a m$ alfadz) with a morphological system. (Taufiqurrochman, 2009) It is a system of arranging entries or word entries based on the root word (jadzr, root word) or essential words, then all the entries or entries of these words are arranged sequentially according to the Arabic alphabet from alif (') to $y \bar{a}^{\prime}(\mathrm{s})$. Therefore, the technique of searching for the location of words in the Arabic dictionary applying a morphological system refers to the root word so that the dictionary user must understand the basics of morphology (Sharaf science) to use the Arabic dictionary implementing a morphological operation. Without understanding the basics of morphology such as essential words, word derivations, and changes in word forms, the user will have difficulty in finding the position of words in the dictionary so that the dictionary applying a morphological system is considered as the delicate and less efficient dictionary. (Hidayat, 2012) As a result, students become lazy to open dictionaries and search for the meaning of Arabic words independently.

It becomes a problem for students at the beginner level who do not understand Arabic grammar, and it is not least for Islamic boarding school students whose learning methods still adhere to the traditional process of reading Kitab Kuning or classical texts in Arabic. (Nurhayati, 2013) Therefore, the focus of this study is the advantages and disadvantages of an Arabic dictionary applying a morphological system and its implications for learning Arabic.

This article describes the advantages and disadvantages of the Arabic dictionary applying a morphological system, as well as the respondents' assessment toward the dictionary implementing a morphological system. This response is required to ascertain the difficulties encountered by students in using the Arabic dictionary, applying a morphological system. By knowing the advantages and disadvantages of the Arabic dictionary implementing a morphological system, dictionary users like teachers and students can choose a dictionary that suits their needs and learning objectives. Likewise, for dictionary compilers and linguists, the results of the study can become recommendations in developing Arabic dictionaries with a more natural new system to overcome the weaknesses of the Arabic dictionary that have been used in Arabic learning.

\section{METHOD}

This article belongs to library research because the object under the study is a dictionary. The approach used is qualitativedescriptive. (Sugiyono, 2016) The writer makes an exploration effort on Arabic dictionaries in Indonesia, which apply a morphological system and which is popularly used by teachers and students in Arabic learning. (Sugiyono, 2010)

In searching and compiling data, the writer used the documentation technique and distributed questionnaires randomly using the snowball technique in which it is done gradually over two months until the respondents reached 100 people. In its practice, the writer used Google Forms that are distributed through social media such as WhatApps and Facebook so that data can be collected more quickly and efficiently. The respondents of this study are heterogeneous because they come from various educational backgrounds and several educational institutions, both public and private, formal, informal, and non-formal.

In analyzing the data, the writer uses qualitative content analysis and the theory of lexicography analysis that has been used by Imel Badi' Ya'qub (1981) in researching Arabic dictionaries. This analysis aims at determining the advantages and disadvantages of the Arabic dictionary by examining the systematic model used by the dictionary. Also, the writer analyzed the data from respondents quantitatively using percentage calculations. Then, the writer classified and tabulated the data becoming some typologies to know what did the obstacles face by dictionary users and what are their hopes to increase the growth of Arabic dictionaries in Indonesia rapidly by the objectives of Arabic learning and the level of dictionary users. 
FINDINGS

\section{Arabic Dictionary Applying a Morphological System in Indonesia}

The language dictionary applying a morphological system is a dictionary in which the composition of entries and sub-entries follows the morphological system, which is a way of forming words by connecting one morpheme to another morpheme. Morphemes are the smallest grammatical units that have the meaning. (Chaer, 2012) Therefore, all entries are arranged in the dictionary, applying a morphological system referring to morphemes, both free morphemes and bound morphemes. In the Arabic dictionary utilizing a morphological system, free morphemes are as entries, and bound morphemes are as subentries. (Nasution, 2017)

Imel Ya'qub (1981) in his study on the Arabic to Arabic dictionaries in 1981, he did not mention the dictionary applying morphological system. Still, dictionary utilizing the comprehensive alphabetical system (Alifbai 'Aam) because after the morphological process and finding the root word, the user refers to the order of the alphabet letters from alif (') to $y \bar{a}^{\prime}(\mathrm{s})$ as the Latin dictionary from A to $Z$. The writer considered that this is just a difference in terms of the dictionary applying a morphological system and dictionary implementing the general alphabetical system because the methodology is the same.

The history of the development of Arabic dictionaries in Indonesia is different from the development of Arabic dictionaries in Arab countries. Arabic dictionaries in Arabic begin with the preparation of a monolingual dictionary, which is an Arabic to Arabic dictionary that places Arabic as the source language as well as the target language. (Imel, 1981) Whereas, Arabic dictionaries that grew and developed in Indonesia began with the emergence of bilingual dictionaries, which are dictionaries that place Arabic as the source language and Indonesian as the target language, or vice versa. (Taufiqurrochman, 2009) Bilingual dictionaries are also called translation dictionaries because their primary function is to translate from one language to another, from a foreign language into a native language.

The early historical differences of the dictionary emergence affect the systematic deviations of the arrangement of the pronunciation dictionary. In the history of Arabic pronunciation dictionaries, there were five kinds of systematics, namely: phonetic system (nizam shawty), hijaiyah system (nizam hijai), rhyme system (nizam qawafi), morphological system (nizam shawty), and the articulate system (nizam nuthqi). (Taufiqurrochman, 2008) Meanwhile, the developed pronunciation dictionaries in Indonesia since the beginning of the emergence of the Arabic dictionary until now, it was found only 2 (two) systems, which are: morphological system (nizam sharfi) and articulative system (nizam nuthqi). Of these two systems, the first system (morphological system) is still popular and is used in educational institutions for Arabic learning as well as classic books written in Arabic.

The Arabic dictionary applying a morphological system has several characteristics. The first feature, this dictionary uses the approach (madkhal) pronunciation dictionary, not a meaning dictionary. A pronunciation dictionary is a dictionary that is in the process of collecting and searching vocabulary based on the form of words (bina 'lafdz). (Umar, 1998) For example, users who want to find the meaning of the word / ma-d-ra-sa-h / must be able to understand the root word (jadzr) of the word. The word / ma-d-ra-sa-h / comes from / da-rasa /, thus the user must look for the meaning of the word / ma-d-ra-sa-h / in the section of $d \bar{a} l$ (\lrcorner$)$. Meanwhile, the meanings dictionary is a dictionary in which the process of collecting and searching vocabulary is based on the meaning of the word (ma'na kalimah), not the form of words. For example, the word / ma-dra-sa-h / should be known its word meaning, which means 'school.' After knowing the meaning, the user refers to a specialized dictionary, which is predicted containing a collection of vocabulary that contains the meaning of 'school,' for example, an education dictionary because 'school' is part of 'education.' In this way, it is concluded that the meaning dictionary refers to the field of meaning (maidan ma'na) in the process of searching for vocabulary in the dictionary, not referring to the form of words (bina 'lafdz).

The second characteristic, the dictionary applying morphological system, follows the morphological method (sharf manhaj), which refers to the derivation of words (isytiqaq) and 
root words (jadzr kalimah). Therefore, users must know the basics of morphology to be able to use a morphological system dictionary. Moreover, the derivation of words in Arabic is a necessity. One word in Arabic can have dozens of words derivation, and their meanings can be different. Therefore, Arabic is known as a language that is 'rich in meaning' but 'poor in words' because one word has the potential of having multiple meanings (musytarak lafdzi, muta'addid ma'na). For example, from the root word / d-r-s / turn into / da-ra-sa / (meaning: has learned; fi'il madhi form or the past verb), / ya-d-ru-su / (meaning: learning; fi'il mudhari' form or present verb), / da-rs / (meaning: lesson; masdar form or noun), / da-a-ri-s / (meaning: students; fa'il form or subject word), / mu-da-r-ri-s / (meaning: teacher; fa'il form or subject word), / ma-d-ra-sa-h / (meaning school; form of dzarafmakan or adverb of place), / di-ra-sa-h / (meaning: science; isim form or noun form), and many more.

The third characteristic, the dictionary a morphological system, uses the structure of the entries and sub-entries. The entries are the original words or root words, while sub-entries are derived words, derivations, or derivative words from the root word. The existence of the entries and sub-entries structure in the dictionary applying a morphological system is a consequence of the use of morphological methods (manhaj sharfi) in the morphological system. Employing the structure of the entries and sub-entries causes the size of the dictionaries applying a morphological system to be larger, thicker, and more oppressive. The more entries and sub-entries loaded, the more complete the contents of the dictionary. Therefore, a good and complete dictionary applying a morphological system is a thick dictionary because it contains the root word and its derivation.

The fourth characteristic, the vocabulary contained in the dictionary applying a morphological system, is always given a way of reading (shakal), especially in the entries or root words. For example, / da-ra-sa / - / yes-dru-su / in this entry, the letter $r a(\jmath)$ in the entry / da-ra-sa / is punctuated (syakal) 'fathah', while in the entry / yes- d-ru-su /, the letter $r a($,$) is punctuated (shakal) 'dhammah'.$ The changes in punctuation in this entry, morphologically, are influenced by changes in word rhythm (bina 'wazan) from past verbs to present verbs. These form changes must be marked by changes in punctuation (shakal) in the dictionary, so that users can understand the changes, distinguish between root words and derivative word, and be able to produce words according to the rhythm formula (wazan) in morphology (sharaf science).

The fifth characteristic, the Arabic dictionary applying a morphological system is usually equipped with examples of the use of words in sentences. The existence of this example sentence makes the users knowing the context of the use of words that may make the meaning of each word to change when it is in a different context because the derivation of words and changes of the form of words have different meanings. Generally, the dictionaries applying a morphological system with example sentences are large dictionaries containing more than 60,000-word vocabulary entries. Medium (basith) or small (wajiz) dictionaries, usually not equipped with examples of word usage.

Based on the five main characteristics of the Arabic dictionaries applying a morphological system above, the researcher found 7 Arabic-Indonesian dictionaries with this system, which are: Mahmud Yunus (1972), kamus Arab-Indonesia by Ahmad Warson Munawwir (1984), kamus al-Qolam ArabIndonesia Indonesia-Arab by Ahmad Sya'bi (1997), kamus Arab-Indonesia by Abu Rifqi alHanif and Nur Kholis Hasin (2000), kamus alAkmal Arab-Indonesia by Syarif al-Qusyairi (2012), Kamus at-Taufiq Arab-Jawa-Indonesia by Taufiqul Hakim (Al-Hakim, 2013), and kamus al-Wafi Arab-Indonesia by A. Thoha Husein al-Mujahid and A. Atho'ilah Fathoni alKhalil (2016).

The writer does not include a dictionary with an approach of 'Indonesia-Arab' because this type of dictionary does not apply a morphological system. However, it use alphabetical order of Bahasa Indonesia, such as kamus Indonesia-Arab by As'ad al-Kalali (1989), kamus al-Bisri Indonesia-Arab ArabIndonesia by Adib Bisri and Munawwir(1999), kamus al-Munawwir Indonesia-Arab by Warson Munawwir (2007), kamus al-Ashri IndonesiaArab by Atabik Ali (2008), kamus al-Kamal Indonesia-Arab by Karisun AS and Rahman (2010), and kamus al-Muzaki Indonesia-Arab Arab-Indonesia by Ahmad Muzaki (2010). 


\section{Reasons for the Use of the Arabic Morphological System}

In learning foreign languages, including Arabic, students cannot escape from the use of dictionaries to understand the meaning of words that they do not understand. This data shows that $100 \%$ of respondents who learned Arabic have used dictionaries as a media to help understand the meaning of words.

Furthermore, out of the 100 respondents, $80 \%$ claimed too often to refer to the dictionary, $10 \%$ claimed sometimes, $10 \%$ claimed rarely refer to it, and no respondent had never used an Arabic dictionary.

This data shows that dictionaries are still an effective learning medium to help students understand foreign languages, including Arabic, especially in translating vocabulary that they do not understand. Moreover, vocabulary in Arabic has multi-meaning characters like the word / dza-ha -ba / can mean: go, walk, pass, die, end, finish, forget, think, disappear, lose mind, gild with gold. (Munawwir, 1984) These meanings can only be known from the dictionary as a standard book containing official vocabulary in Arabic whose meaning has been agreed upon by Arabic language users.

What do respondents do, if they do not understand the meaning of the word in Arabic? The following are the results of the respondents' answers.

The search for the meaning of words through the dictionary is still the most frequent activity of the respondents when they do not understand the meaning of words in Arabic. If it is so, then what is the best dictionary according to the respondents? They agreed that Kamus al-Munawwir Arab-Indonesia compiled by Ahmad Warson Munawwir was the best dictionary. Their reasons for choosing Kamus al-Munawwir are very diverse.

The respondents' reasons to choose Kamus al-Munawwir as the best dictionary include: 1) The dictionary is rated the most complete; 2) The dictionary helps in understanding the meaning of Arabic words; 3) the only dictionary they have; 4) The dictionary is composed by the linguists and dictionary experts; 5) The dictionary is a mandatory dictionary in their schools; 6) Being recommended by their teachers; 7) Other reasons.
Although the respondents could rate the best Arabic dictionary, the writer found data showing that the majority of respondents $(85 \%)$ did not know and did not understand the morphological system in the Arabic lexicon. It means they do not yet know the science of the dictionary (lexicology-lexicography).

The results of interviews reveal the fact that they have not yet learned that required knowledge and often ignore explanations about the use of dictionaries. A tutorial on using dictionaries is essential to be known and determined by every dictionary user. Each dictionary has different characters, approaches, models, and entry and sub-entry settings.

\section{Problems of the Arabic dictionary applying a morphological system}

In reality, the writer found problems faced by respondents as users of the Arabic dictionary using a morphological system.

The most common problems in using the Arabic dictionary applying a morphological system is that respondents need a long time to find the location of words in the dictionary implementing a morphological system. Next, they find it difficult to understand the meaning of words; the contents of the dictionary do not include examples of the use of words according to the context of the sentence. Additionally, the size is too thick, the translation of words is not correct, the price is high, and other reasons.

The data above shows that most of the problems faced by students or the dictionary users are in finding the entry words in the dictionary, so it takes a long time (36\%). It is fair because a dictionary with a morphological system is based on basic words. While Arabic words consist mostly of derivative words, the user must spend time to find out where the basic words located in the dictionary. Besides, the dictionary user must do a morphological analysis, and this is undoubtedly difficult for students or dictionary users who do not understand the basics of Arabic morphology.

The second most common problem in the use of morphological dictionaries is the difficulty of students in understanding the meaning of words (18\%). It shows that the morphological dictionary contains lexical meanings which are identical to word-forword meanings. The dictionary does not always display contextual purpose or meaning 
that fits the integrity of the discourse and the needs faced by users in understanding Arabic. Therefore, term dictionaries that are specific to the field of science are needed, such as medical dictionaries, political dictionaries, and educational dictionaries. In contrast, most morphological dictionaries are dictionaries for general terms so that the meaning of the words contained in the morphological dictionary is only lexical meaning, not contextual.

\section{ANALYSIS}

Each dictionary has advantages and disadvantages. Each dictionary also has different characteristics and selling points, although it adopts the same morphological system. The applying a morphological system is the first Arabic dictionary compiled by Indonesian lexicologists such as Mahmud Yunus, Muhammad Idris al-Marbawi, Ahmad Warson Munawwir, and others. (NU, 2012) The dictionary applying a morphological system does not only describe the translation of words from Arabic to Indonesian. However, it is also complemented by a review of word changes, variations in word meanings, and other explanations related to morphological and semantic studies.

For example, the words / ra-ju-lu / and / ma-s-ji-d / in the singular are explained by the dictionary in its irregular plural being / ri-ja:lu / and / ma-sa:-ji-d /. (Munawwir, 1984; Sya'bi, 1997; Yunus, 1989) Or conversely, from plural words such as / ai-ha-m / and / ah-ya-f / the singular form is explained as / ba-h-ma-a / and / ha-i-fa-a '/. For example, the dictionary describes absorption words from foreign languages into Arabic such as / ra-di-yu / from the radio, / ka-m-bi-yu-ti-r / from the computer. The morphological dictionary sometimes also mentions slank (amiyah) such as: / si-n-da-na-h / meaning flower vase, / hafi-ya / meaning very hungry, / wa-tsa-r / meaning shorts.(Munawwir, 1984)

The morphological dictionary also explains the change in word forms from male to female, such as: / ah-ma-r / and / ha-m-ra '/.(al-Hanif \& Hasin, 2000; Al-Mujahid \& AlKhali, 2016) The most important thing from the morphological dictionary is the explanation of the change of verb form from the past verb (madhi) to the present verb, such as / fa-a-la / to / yaf-'u-lu / or / yaf-'i- lu / or / yaf-'a-lu / and so on. This verb shape change is an essential theme in the morphological dictionary because students or users of the dictionary cannot make verb shape changes based on instincts or estimates, but must refer to the rules of neuroscience that are also embraced by the morphological dictionary.

Therefore, lexicologists in Indonesia compile an Arabic dictionary applying a morphological system because they assess a dictionary implementing a morphological system to help students learn Arabic (linguistics), especially morphology and syntax, which is undoubtedly very needed in reading Kitab Kuning (classic books) arranged in Arabic. (Taufiqurrochman, 2014) Lexicologists respond to students' needs for this dictionary by publishing the dictionary applying a morphological system. (Masrur, 2018) Therefore, a dictionary implementing a morphological system is found in Islamic boarding schools and religious education institutions which study Kitab Kuning and classical-intellectual related thing. (Iryana, 2015)

\section{The Advantages of an Arabic dictionary applying a morphological system}

Based on the writer's analysis and the respondents' reasons as users of the dictionary implementing a morphological system, it was found several advantages possessed by that dictionary.

First, the dictionary applying a morphological system is considered complete because: a) there are symbols that explain the way of pronouncing the words; b) the definition is presented correctly and efficiently; c) displaying the essential concepts and their derivatives ranging from the simplest to the most complex affixations; d) the term chosen is the term that has the highest usage frequency. (Taufiqurrochman, 2008)

Second, the dictionary applying a morphological system meets the criteria of the dictionary function, namely: explaining the meaning of the word (syarah ma'na), explaining articulation or how to pronounce the word (bayan nuthq), describing the character of hijaiyah letters (bayan hija), helping to search for the root word ( $t a^{\prime}$ shil isytiqaqi), giving morphological and syntactic information (ma'lumat sharfi wa nahwi). (Taufiqurrochman, 2009) 
Syntactic information is most often found in changes in the meaning of transitive verbs that are strongly influenced by the subject or object, such as the word / dha-ra-ba / having many meanings depending on the subject and object. The word / dha-ra-ba / can mean: move, sting, length, go, hit, print, hold, settle, swim, blow, knock, cut, bomb, call, travel, separate, run, or mix. (Munawwir, 1984, pg. 872) The variety of meanings of one word shows the richness of meaning in the Arabic vocabulary. The positive side of this variety of meanings is to help users enrich mastery of the meaning of words in Arabic and provide meaning choices in translating and understanding Arabic texts. However, the negative side of these various meanings is to make students or users of the dictionary confused in choosing the right meaning of the word.

The only dictionary function absent from the dictionary applying a morphological system in Indonesia is the information about word usage (istikhdam kalimah) such as old and new vocabulary information (qidam hadats), universal level of words (syuyu'iyah), cultural and social level in terms (tsaqafah ijtima'iyah) and the level of word usage based on the location or region of origin of the word (iqlim istikhdam). (Taufiqurrochman, 2008)

Third, the dictionary applying a morphological system helps students learn the Sharaf (morphology) and Dalalah (semantics). When using the dictionary with the morphological system, students are required to analyze words by looking for root words, forms of derivatives, types of word construction and rhythms (bina 'wa wazan), and the use of words in sentences. (Imel, 1981) Also, when students find various meanings of a word, they are free to choose the right translation for their context. It means that students can learn the science of meaning (semantics) through the dictionary, applying a morphological system.

This reality shows that the dictionary is not only as a reference to search for the meaning of words but also as a medium for learning morphology and semantic Arabic. Through dictionaries, students can practice analyzing words from various aspects, in terms of meaning, changes in word forms, spelling, synonyms, and antonyms. Meanwhile, media for the practice of morphology and syntax are very minimal in addition to books on morphological and syntactic theories. Therefore, morphological dictionaries are very appropriate for students at the elementary level who are learning language rules from aspects of words and meanings.

\section{The Disadvantages of Arabic dictionary applying a morphological system}

Based on the writer's analysis and the respondents' reasons as users of the dictionary implementing a morphological system, it was found several disadvantages possessed by that dictionary.

First, respondents or users of the dictionary applying a morphological system find it difficult to analyze the root word because this requires an understanding of Sharaf science. Students often face this difficulty at the beginner level who are just Arabic learning or get to know the Arabic dictionary characters.

Second, the process of searching for words and understanding their meaning takes a long time because the user must go through the procedures of root word analysis and derivative word. As a result, they began to leave the Arabic dictionaries applying a morphological system because they were considered less efficient.

Third; The Arabic dictionary applying a morphological system is generally large and thick in size, the weight is massive, and the price is relatively high; thus, this dictionary is less practical to be carried everywhere. As a result, the dictionary applying a morphological system is not used during the learning process. Even, some respondents claimed to start switching to electronic dictionaries because they had been integrated with the cellphones they always carried. (Taufiqurrochman, 2019)

Fourth, the process of compiling the language dictionary applying a morphological system is also longer because a lexicologist must put together one word with all of its derivatives and different meanings of words. It takes a long time from collecting entries and sub-entries, selecting and analyzing words, translating, and writing to publishing the dictionary. 


\section{The implication of Dictionary applying a Morphological System on Arabic Learning}

Arabic dictionaries implementing a morphological system have significant impact and contributions to the development of Arabic and its learning in Indonesia.

First; The dictionary applying a morphological system helps students learn independently about the basics of morphology (Sharaf science), a science that is important to be mastered by students leaning Arabic because the object of Sharaf science is the words form changes. In contrast, words are one of the three elements of language. When students look for the location of terms, then directly, they analyze the word by tracing the root word. Furthermore, when students find the root word in the dictionary applying a morphological system, they will also find various forms of derivative words or derivations of the word. This process will enrich the students' knowledge in understanding the character of words and their meanings in Arabic. The ability to analyze words and understand various purposes is the main asset in reading Kitab Kuning.

It is different from other system dictionaries, such as the articulative system dictionary (nizam nuthqi). The dictionary applying an articulative system indeed speeds up the search for the location of words in the dictionary because users or students do not need to search for word roots. For example, searching for the word / ma-d-ra-sa-h / can refer directly to chapter Mim (م) because / mad-ra-sa-h / articulately begins with the letter Mim (ค). (Ali \& Muhdlor, 2003) This technique is indeed faster, but students do not have experience in analyzing the root word of / ma$\mathrm{d}$-ra-sa-h / which is originally from the word / da-ra-sa /. Students also do not have the opportunity to enrich vocabulary through a variety of derivations that are allied to the words / ma-d-ra-sa-h / like / da: -ri-s /, / muda-r-ri-s /, / da -ra-sa /, / di-ra-sa-h /, etc. The set of words and meanings in one entry can only be found in the dictionary, applying a morphological system, not in the dictionary, applying an articulate system.

The writer concluded that the dictionary using a morphological system is not appropriate for students at the beginner level who are learning to know Arabic. Because, at the beginner level, students are not equipped with grammar knowledge such as morphology (Sharaf), syntax (Nahwu), and semantics (Dalalah). Students at this level are still at the stage of enriching Arabic vocabulary and basic sentence patterns that are commonly used for daily communication, so it is not appropriate if students are forced to use a dictionary applying a morphological system.

According to the writer, the right dictionary for students at the beginner level is the thematic dictionary (maudhu'i), which is a dictionary that collects vocabulary according to themes and teaching material. Thematic dictionaries are not compiled by a morphological system, but by an articulate system (nizam nuthqi). By using thematic dictionaries, students can learn to pronounce and write words correctly, understand the meaning of words quickly without having to know the root word and its derivation. The Arabic dictionary applying a morphological system fits for students at intermediate and advanced levels because they begin to study grammar.

Second, the Arabic dictionary applying a morphological system must be part of the Arabic learning tool. In the Arabic curriculum, it is necessary to include recommendations about dictionaries that must be learned by students and must be brought during the learning process. In studying Kitab Kuning (classic book), students must be equipped with a dictionary applying a morphological system so that they can understand the contents of the book independently because an Arabic dictionary has accompanied them.

Therefore, research on Arabic dictionaries in Indonesia is still needed to produce excellent and complete specifications of the Arabic dictionary according to the needs and learning objectives. Research on dictionaries is useful to find out the disadvantages or weaknesses of Arabic dictionaries on the market. Remember, not all dictionaries contain accurate translation. The dictionary compiled in the past several years also needs to be revised so that the vocabulary compiled in the Arabic dictionary is standard, not the slang language (ammiyah), and the translation of words from Arabic to Indonesia is also correct according to Indonesian grammar rules. Dictionaries that do not comply with Arabic and Indonesian language 
standards have a significant effect on students learning foreign languages, including Arabic.

\section{CONCLUSION}

In the history of the development of Arabic dictionaries in Indonesia, the arrangement of Arabic dictionaries began with the morphological system. Until now, the dictionaries applying a morphological system are still used in Arabic learning. The advantages of the dictionary implementing a morphological system are that it is assessed more fully; the functions and benefits of the dictionary are fulfilled; it helps students learn the basics of Sharaf science (morphology). Meanwhile, the lack of a dictionary applying a morphological system is the difficulty of students in analyzing root words. It takes a long time to find the location of terms; the size is thicker and weighty; the price is high; it is difficult to carry anywhere. The existence of a dictionary applying a morphological system has implications for Arabic learning in Indonesia because this type of dictionary encourages students to learn the basics of morphology as a provision for reading Kitab Kuning. The dictionary applying a morphological system is suitable for students at the intermediate or advanced level. It is compatible with the method of Kitab Kuning learning in an Islamic boarding school, which uses the technique of reading and translating (qira'ah wa tarjamah). However, the dictionary applying a morphological system is not appropriate for students at the beginner level. Therefore, in the Arabic language education curriculum, it is necessary to include recommendations about relevant dictionaries for students according to their level of education, teaching material, and their needs.

\section{REFERENCES}

Abdul Wahab, M. (2017). Peta Perkembangan Leksikografi Arab dI Indonesia: Studi Kritis atas Kamus karya Mahmud Yunus [Map of the Development of Arabic Lexicography in Indonesia: Critical Study of the Dictionary by Mahmud Yunus]. Arabi: Journal of Arabic Studies, 2(1), 19. https://doi.org/10.24865/ajas.v2i1.31

al-Hanif, A. R., \& Hasin, N. K. (2000). Kamus Arab-Indonesia. Surabaya: Terbit Terang.

Al-Hakim, T. (2013). Kamus At-Taufiq Arab-Jawa-Indonesia. Jepara: Amtsilati.

Ali, A. (2008). Kamus Al-Ashry Indonesia Arab. Yogyakarta: Multi Karya Grafika.

Ali, A., \& Muhdlor, A. Z. (2003). Kamus Krapyak Al-Ashry Arab-Indonesia. Yogyakarta: Multi Karya Grafika.

Al-Mujahid, A. T. H., \& Al-Khali, A. A. F. (2016). Kamus Al-Wafi Arab-Indonesia. Jakarta: Gema Insani Press.

Al-Qusyairi, S. (2012). Kamus Al-Akmal Arab-Indonesia. Surabaya: Karya Harapan.

Bisri, A., \& Fatah, M. A. (1999). Kamus Al-Bisri Indonesia-Arab Arab-Indonesia. Surabaya: Pustaka Progressif.

Busro, M. M. (2016). Sejarah Perkamusan Bahasa Arab di Indonesia [History of Arabic Language in Indonesia]. El-Wasathiya: Jurnal Studi Agama, 4(2), 129-158.

Chaer, A. (2012). Linguistik Umum [General Linguistics]. Jakarta: Rineka Cipta.

Hidayat, N. S. (2012). Problematika Pembelajaran Bahasa Arab [Problematic Learning Arabic]. AnNida', 37(1), 82. 
Imel, Y. (1981). Al-Ma'ajim Al-Lughawiyyah Al-'Arabiyyah [Arabic dictionaries]. Bairut: Dar al Ilm lil Malayin.

Iryana, W. (2015). Tantangan Pesantren Salaf di Era Modern [The Challenge of the Salaf Boarding School in the Modern Era]. Al-Murabbi, 2(1), 64-87.

Masrur, M. (2018). Mengupas Kamus al-Marbawi Karya Ulama Nusantara [Examining al-Marbawi's Dictionary by Ulama Nusantara]. Diambil 30 September 2018, dari Bincang Syariah website: https://bincangsyariah.com/khazanah/mengupas-kamus-al-marbawi-karya-ulamanusantara/

Munawwir, A. W. (1984). Kamus Al-Munawwir Arab-Indonesia. Yogyakarta: Pondok Pesantren AlMunawwir.

Munawwir, A. W. (2007). Kamus Al-Munawwir Indonesia-Arab. Surabaya: Progressif.

Muzaki, M. (2010). Kamus Muzaki Indonesia-Arab Arab-Indonesia. Surabaya: Gama Press.

Nasution, S. (2017). Linguistik Bahasa Arab [Arabic linguistics]. Sidoarjo: Lisan Arabi.

NU, E. (2012). Mengenal Kamus Al-Marbawi [Get to know the Al-Marbawi Dictionary]. Diambil 30 September 2018, dari NU.or.id website: http://www.nu.or.id/post/read/41180/mengenalkamus-al-marbawi

Nurhayati, A. (2013). Literatur Keislaman dalam Konteks Pesantren [Islamic Literature in the Context of Pesantren]. Pustakaloka, 5(1).

Rahman, K. AS. (2010). Kamus Modern Al-Kamal Arab-Indonesia. Surabaya: Pustaka Progressif.

Rizani, H. (2014). Kamus Idris Al-Marbawi dalam Tinjauan Leksikologi: Analisis Metode dan Isi [Idris Al-Marbawi's Dictionary in a Lexical Review: Analysis of Methods and Content]. alfaz, 2(2), 224-237.

Sugiyono. (2010). Metode Penelitian Pendidikan [Educational Research Methods]. Bandung: Alfabeta.

Sugiyono. (2016). Metode Penelitian [Research Methods]. Bandung: Alfabeta.

Sya’bi, A. (1997). Kamus Al-Qalam Arab-Indonesia Indonesia-Arab. Surabaya: Halim.

Taufiqurrochman, R. (2008). Leksikologi Bahasa Arab [Arabic Lexicology]. Malang: UIN Malang Press.

Taufiqurrochman, R. (2009). Dirasah Mu'jamiyah: Nasy'atuha wa Nadzariyatuha wa Madarisuha [Lexical Study: Its Origins, Theories and Schools]. al-Ittijah, 1(2). Diambil dari http://jurnal.iainbanten.ac.id/index.php/al-Ittijah/article/view/14

Taufiqurrochman, R. (2014). Tashnif al-Ma'ajim al-'Arabiyah wa Tathwiruha fii Indonesia: Dirasah Washfiyah Tahliliyah Tathwiriyah [Classification and Development of Arabic Dictionaries in Indonesia: Descriptive and Analytical Developmental Study]. Universitas Islam Negeri Maulana Malik Ibrahim.

Taufiqurrochman, R. (2019). The Use of Arabic Electronic Dictionaries in The Industrial Revolution Era 4.0. EasyChair.

Umar, A. M. (1998). Shina'at al-Mu'jam al-Hadits [Modern Lexicology]. Baerut: 'Alam el-Kutub. 
Wahida, B. (2017). Kamus Bahasa Arab sebagai Sumber Belajar: Kajian terhadap Penggunaan Kamus Cetak dan Kamus Digital. [Arabic Dictionary as a Learning Resource: Study of the Use of Print Dictionaries and Digital Dictionaries]. At-Turats, 11(1). https://doi.org/10.24260/atturats.v11i1.870

Yunus, M. (1989). Kamus Arab-Indonesia. Jakarta: PT Hidakarya Agung. 
LiNGUA Vol. 14, No. 2, December 2019 • ISSN 1693-4725 • e-ISSN 2442-3823

282 | Advantages and Disadvantages of Arabic Dictionary Applying Morphological System 